\title{
Do Remittances Have a Flip Side? A General Equilibrium Analysis of Remittances, Labor Supply Responses and Policy Options for Jamaica
}

\author{
Maurizio Bussolo \\ The World Bank \\ Denis Medvedev \\ The World Bank
}

\begin{abstract}
Econometric analysis established a negative relationship between labor supply and remittances in Jamaica. We incorporate this ex-post evidence in a general equilibrium model to investigate economy-wide effects of increased remittance inflows. In this model, remittances reduce labor force participation by increasing reservation wages of recipients. This exacerbates the real exchange rate appreciation, hurting Jamaica's export base and small manufacturing importcompeting sector. Within the narrow margins of maneuver of a highly indebted government, we show that a revenue-neutral policy response of a simultaneous reduction in payroll taxes and increase in sales taxes can effectively counteract these potentially worrisome effects of remittances.
\end{abstract}

- JEL classification: D58, F24, J22, H24, H31

- Key words: Jamaica, remittances, labor supply, tax policy, general equilibrium

\footnotetext{
*Maurizio Bussolo: Economic Policy Sector, Latin America and the Caribbean Region, I4-405, The World Bank, 1818 H St NW, Washington, DC 20433, USA, Tel: 202-458-2619, Fax: 202-522-2119, Email: mbussolo@worldbank.org, Corresponding author: Denis Medvedev: Development Prospects Group, MC2-200, The World Bank, 1818 H St NW, Washington, DC 20433 USA, Tel: 202-473-3895, Fax: 202-522-22578, E-mail: dmedvedev@ worldbank.org.

The findings, interpretations, and conclusions expressed in this paper are entirely those of the authors. They do not necessarily reflect the view of the World Bank, its Executive Directors, or the countries they represent. 


\section{Introduction}

What is the role of international remittances in the economic development of recipient countries? This important question is not completely new, and some answers have already been provided by the large literature on aid effectiveness: the effects of remittances depend on how they are used. ${ }^{1}$ If remittances are spent on consumer goods, they are likely to have limited to no impact on domestic investment and thus do little to enhance long-term economic growth. Instead, they may create dependency and contribute to real exchange rate appreciation, eroding the competitiveness of domestic firms. A related issue is whether remittances could lead to an increase in reservation wages of recipients and thus induce reductions in the labor supply. In this case, the real exchange rate appreciation is likely to be more pronounced, the potential negative effects more severe, and options for public policy response unclear.

This paper considers the case of Jamaica, a country that during the 1990s witnessed a combination of declining labor force participation rates and a remarkable increase in international remittances inflows. Working with the 19952002 Jamaican household surveys, Kim (2006) finds a significant negative relationship between increased remittances and labor supply decisions of Jamaican households. Taking into account this finding, this paper constructs and calibrates a computable general equilibrium (CGE) model of Jamaica with an endogenous labor supply to address two main issues. First, it assesses the potential economywide repercussions of a labor supply reduction and real exchange rate appreciation due to an increase in remittances. Second, it investigates potential corrective policies that the government could implement to address the negative effects on labor supply and competitiveness. A revenue neutral change in the tax structure, involving a reduction of direct taxation with a concurrent increase of indirect taxation, is the central policy change investigated here. The most straightforward reduction in direct taxes is a cut of payroll taxes, however one can also think of other polices that increase labor market flexibility and ultimately support labor demand. The costs of such tax cuts need to be taken into account, especially in the case of a very highly indebted country such as Jamaica, and in our simulation a compensatory increase in sales tax rates maintains the government balance unchanged. A major result of this paper is that a revenue-neutral policy that

${ }^{1}$ See, for example, Burnside and Dollar (2002) and Collier and Dollar (2002). 
reduces labor costs can almost completely sterilize the negative labor supply effect of rising remittances-an encouraging outcome for a country struggling with falling labor force participation.

The paper is organized as follows. The next section provides some background information on the Jamaican labor markets, remittance flows and on the still sparse evidence on the links between these flows and labor supply provided by the recent literature. Section briefly presents the analytical structure of our model and the basic dataset it utilizes. Section Remittances, labor supply, and the Jamaican economy: a numerical analysis of their interdependence and an assessment of policy options describes the scenarios and the results, both at the aggregate and detailed sectoral level. Section Conclusions offers concluding remarks.

\section{Remittances and Labor Markets in Jamaica}

The importance of remittances in Jamaica has been growing rapidly, particularly so since the early 1990s (Figure 1). In 2002, remittances accounted for 14.3 percent of GDP and financed 19.8 percent of household consumption. Furthermore, remittances were approximately half of all financial inflows from the rest of the world and therefore contributed significantly to financing the current account gap. In real terms, the average annual growth between 1976 and 2003 has been 7.8 percent. Even more striking is the growth over the last ten years, when the volume of remittances grew at an average annual rate of 18.2 percent. During the same time, the share of remittances in household consumption and GDP grew by 14 and

Figure 1. Evolution of Remittances in Jamaica.

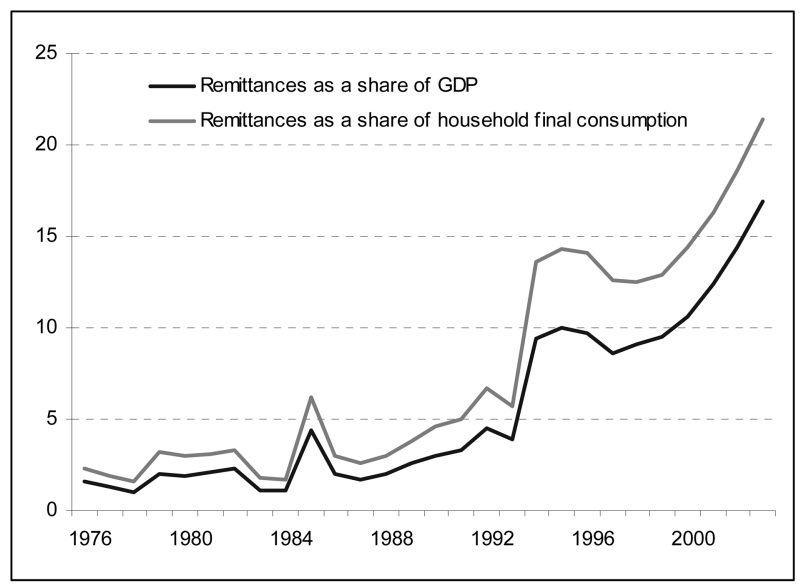


15 percent per year, respectively.

In addition to very rapid growth of remittances, the 1990s witnessed steadily declining labor force participation rates in Jamaica, which fell from $77 \%$ to $72 \%$ for men and 59\% to 52\% for women. World Bank (2006a) characterizes Jamaica as "one of the few countries in Latin America in which labor force participation rates have had a negative impact on the growth of labor supply." At the same time, real wages have exhibited strong growth: between 1995 and 2002, average real weekly earnings have almost doubled (World Bank, 2006a). There are several reasons why workers have not responded to rising wage incentives by increasing their participation. One explanation may be that excessive labor market rigidity creates barriers to entry of new (or unemployed) individuals in the job market. Alternatively, it may be that many potential workers are waiting for better job offers given that their reservation wages are too high.

Labor market rigidity, which may be due to excessive workers bargaining power and or excessive regulations, does not seem to be a major issue for Jamaica, at least if one considers the available empirical evidence. Table 1 shows that, apart from relatively high firing costs, Jamaica's labor market seems fairly flexible. In particular, the 22.6 score on the collective relation index, puts Jamaica below the score of the US (25.8) and very close to that of the UK (18.5). Jamaican unionization rates have decreased to about $16 \%$ in the first half of the 1990s from just below $30 \%$ twenty years earlier. ${ }^{2}$ As estimated by Heckman and Pages (2003), non-wage costs of labor market regulations are low in Jamaica relative to the rest of Latin America and Caribbean. For Barbados, Trinidad and Tobago, and Jamaica - the three Caribbean countries included in their survey of studies on Latin America-the authors conclude that "the effects of job security on employment are statistically insignificant and the signs are positive in some cases."

Even if it does not constitute a formal test, this evidence casts some doubts on the validity of the excessive rigidity hypothesis. On the other hand, is it possible that the fast growth of remittances has resulted in rising reservation wages and reduced labor force participation? There is very little scientific evidence to substantiate the common preconception that remittances elicit reductions in the labor force participation of recipient households. Controlling for endogeneity represents a major difficulty in empirical tests of this labor supply behavior. In analyses of cross section data, it is quite difficult to establish whether remittances

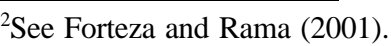


Table 1. Labor Market Rigidity Indicators

\begin{tabular}{lccc}
\hline \multicolumn{1}{c}{ Indicator } & Jamaica & Region & OECD \\
\hline Difficulty of Hiring Index & 11.0 & 40.5 & 30.1 \\
Rigidity of Hours Index & 0.0 & 50.9 & 49.6 \\
Difficulty of Firing Index & 20.0 & 29.5 & 27.4 \\
\hline Rigidity of Employment Index & 10.0 & 40.3 & 35.8 \\
\hline Hiring cost (\% of salary) & 11.5 & 15.9 & 20.7 \\
Firing costs (weeks of wages) & 60.2 & 62.9 & 35.1 \\
\hline Collective relation Index & 22.6 & 46.5 & 46.2 \\
Social Security Index & 16.8 & 57.8 & 73.9 \\
\hline
\end{tabular}

Notes: Four areas are subject to statutory regulation in all countries: employment, social security, industrial relations and occupational health and safety. Doing Business focuses on the regulation of employment. The rigidity of employment index (in italics in the table) is the average of three subindices: a difficulty of hiring index, a rigidity of hours index and a difficulty of firing index. All the subindices have several components, and all take values between 0 and 100, with higher values indicating more rigid regulation. The hiring cost indicator measures all social security payments and payroll taxes associated with hiring an employee. The cost is expressed as a percentage of the worker's salary. The firing cost indicator measures the cost of advance notice requirements, severance payments and penalties due when dismissing a redundant worker, expressed in weekly wages. In Botero et al (2004), the Collective relation index combines information from two sub-areas of the collective action laws: (i) the power granted by the law to labor unions and (ii) the laws governing collective disputes. The sub-index of labor union power measures the power of labor unions over working conditions. The second sub-index measures protection of employees engaged in collective disputes. Higher values of the index are associated to higher workers' protection. The Social security index considers coverage and generosity of pensions, sickness and healthcare insurance, and unemployment.

Sources: For the first 6 rows the Doing Business (2006) website, for the bottom two rows Botero et al (2004).

cause lower labor supply or, conversely, remittances from relatives working abroad are a response to adverse conditions at home and support incomes of family members who have been unable to offer their labor services in the domestic market. Panel data offer better chances to establish exogeneity, but they are still rare for many developing countries.

Apart from the above direction-of-causality concerns, households who receive remittances normally self-select into this group by sending a working member of the household abroad. Therefore, labor supply decisions at the household level are motivated both by the income effect of increased remittances and the substitution effect of having to make up for the lost income of the household member. Depending on the relative magnitude of the two effects, labor supply of remittancereceiving households may thus go up or down. Furthermore, if the number of migrants is non-negligible relative to total employment, emigration may put upward pressure on wages and therefore stimulate additional employment. For 
example, Mishra (2006) estimates that emigration raised average wages by $8 \%$ between 1970 and 2000 in Mexico.

Despite these difficulties, most studies find that on balance, remittances are associated with a decline in the labor supply. World Bank (2006b) shows the labor force participation rates of remittance recipients in Latin America are systematically lower than those for non-recipients, and the negative relationship also holds for hours worked. Rodriguez and Tiongson (2001), who examine the labor force participation of households in Manila in 1991, estimate that having a migrant abroad reduces the probability of working by 9.4 percentage points for men and 18.1 percentage points for women. When remittances are increased from $\$ 0$ to $\$ 40$ per non-migrant family member, men decrease their labor force participation by a third of a percentage point, whereas women respond by reducing their labor force participation by only one-fifth of a percentage point. Funkhouser's (1992) study of households in Nicaragua also concentrates on the responses of urban households. His probit estimates indicate that an increase in remittances from $\$ 0$ to $\$ 100$ decreases male and female labor force participation by 2 and 5 percen- tage points, respectively. However, Funkhouser also finds that self-employment hours increase by about 1 percent for both men and women. Hence, Funkhouser (1992) finds evidence of the work effort shifting across various types of employment on account of remittance receipt.

While not specifically addressing the impact of remittances on total work effort, Matshe and Young (2004) measure the responsiveness of rural households in Zimbabwe to overall non labor income. In particular, they assess how households' decision with respect to supplying their labor to the off-farm labor market is affected by non-labor income flows. They find that these income flows reduce offfarm labor activity. Amuedo-Dorantes and Pozo (2005) carry out a preliminary analysis of the impact that remittances sent by Mexican migrants may have on the labor supply patterns of their working-age male and female family members back home. They find that remittance income sometimes reduces hours worked, whereas other times this inflow increases work effort depending on the type of work, the gender of the recipient, and the location of the household. For the specific case of Jamaica, Kim (2006) constructs a pseudo-panel data using household surveys covering the period 1995 to 2002 and finds a negative impact of remittances on labor market participation. In particular, Kim (2006) estimates that the likelihood of participating in the labor force is reduced by 4 percent for individuals who receive remittances from abroad, although remittances do not seem to affect the number of 
hours worked once an individual has decided to enter the labor market.

\section{General Equilibrium Approach: Advantages, Model Description, and Key Data}

\section{A. Modeling Economy-wide Effects of Increased Remittance Inflows}

Increased remittance flows may raise reservation wages and reduce labor supply; they can also increase pressure on the real exchange rate and worsen export performance. $^{3}$ The sign and magnitude of these complex links depend on many direct and indirect effects and are largely determined by the structural features of the economy and the relevant elasticity values. Tracing these effects requires a general equilibrium model where endogenous labor supply decisions are explicitly incorporated and enough sectoral detail exists to allow for different degrees of tradability across goods.

The computable general equilibrium (CGE) model used in this study is based on a standard neoclassical general equilibrium model. The main features of this model are presented in Annex A brief description of the CGE model and will be familiar to readers accustomed with the CGE literature. We solve the model in a comparative static mode, and our discussion of the results is based on a comparison between the before- and after- the shocks' equilibria. ${ }^{4}$ The remittance shock is imposed as a one-time adjustment in the level of international remittances and is completely exogenous. In this way, increased remittances are analogous to any other increase in current transfers to households from abroad and are not preceded by emigration of an income-earning household member. While this is a simplification of reality, one may think of several cases where this assumption may be appropriate: increase in the living standards of migrants living abroad, reduction of money transfer fees charged by financial institutions, etc. In any case, the objective of this study is not to substitute for the microeconomic studies that investigate the many links between remittances, migration, household labor supply decisions, and within-household distribution of income, but to complement this

${ }^{3}$ Under certain circumstances, remittances can also affect saving and investment behavior and thus future growth-however, we do not consider these dynamic effects in our analysis.

${ }^{4}$ We do not consider the length of time required for a shock to take place or for the policy response to be implemented. Although the dynamic adjustment mechanisms are very important, we choose instead to maintain the focus on the final aggregate and sectoral effects of policies in order to isolate the specific channels that transmit remittance shocks through the economy. 
literature with an analysis that explicitly takes into account general equilibrium effects on macroeconomic aggregates and the external sector.

In order to isolate the specific channels transmitting remittance shocks through the economy, consider first a small open economy model with no leisure-consumption tradeoff. In this setup, an increase in remittances is equivalent to a (permanent) increase in incomes of the households. Assuming that non-tradables are normal goods, this positive income shock increases spending on both tradables and nontradables. Since Jamaica is a price taker in international markets, growing demand does not raise prices of tradables. However, since the prices of non-tradables are determined in the domestic economy, they increase due to additional demand (the so-called 'spending effect'). There is also a 'resource movement effect'. The relative price change between tradables and non-tradables makes production in the latter more profitable. Output growth in the non-tradable sectors will push up factor demands, especially for those factors used intensively in these sectors. Increased factor demand by the expanding sectors will be accommodated by factors released from other sectors (the resource movement effect) and, depending on the behavior of total supply of factor, will normally result in higher factor returns in the final equilibrium. The price shift and resource reallocation in favor of non-tradables erode the competitiveness of export oriented sectors and hurt import competing sectors.

In order to allow changes in remittance inflows to influence the household decision to supply labor, this simple model is modified by introducing a consumption-leisure tradeoff in the household utility function, similar to the approach of Barzel and McDonald (1973), de Melo and Tarr (1992), and Annabi (2003). Consider a Stone-Geary utility function and a budget constraint of the following form:

$$
u=\sum_{i=0}^{N} \mu_{i} \ln \left(C_{i}-\theta_{i}\right) \quad \text { s.t. } \sum_{i=0}^{N} P_{i} C_{i}=Y=W T+y
$$

In this utility function, $C_{i}$ denotes the consumption of good $i$ with leisure $\left(C_{0}\right)$ being a normal good, $\theta_{\mathrm{i}}$ are usually interpreted as consumption minima, ${ }^{5}$ and the share parameters $\mu_{\mathrm{i}}$ (including $\mu_{0}$ ) must sum to unity. $T$ denotes the total time a household has available for work and leisure activities, and the amount of resources available for non-leisure consumption is limited by non-labor income $(y)$

${ }^{5}$ Note that there is no theoretical requirement for any of the $\theta_{\mathrm{i}}$ to be positive. 
and total wage income (ignoring saving and taxes for simplicity). ${ }^{6}$ Constrained maximization gives rise to the familiar linear expenditure system (LES) demand functions:

$$
C_{i}=\theta_{i}+\frac{\mu_{i}}{P_{i}}\left(Y-\sum_{i=0}^{N} P_{i} \theta_{i}\right)
$$

The household labor supply is the difference between total time available and the time allocated to consumption of leisure, and substituting the budget constraint into the demand function yields:

$$
L S=\left(1-\mu_{0}\right)\left(T-\theta_{0}\right)-\frac{\mu_{0}}{W}\left(y-\sum_{i=0}^{N} P_{i} \theta_{i}\right)
$$

Partially differentiating the labor supply equation with respect to non-labor income and the wage rate yields the following elasticities:

$$
\begin{gathered}
\varepsilon_{y}=\frac{\partial L S}{\partial y} \frac{y}{L S}=\frac{\mu_{0}}{W} \frac{y}{L S}<0 \\
\varepsilon_{W}=\frac{\partial L S}{\partial W} \frac{W}{L S}=\frac{\mu_{0}}{W^{*} L S}\left(y-\sum_{i=0}^{N} P_{i} \theta_{i}\right)
\end{gathered}
$$

While the labor supply is decreasing in non-labor income, the sign of the wage elasticity depends on the ratio of non-labor income to the total "committed" consumption expenditures. ${ }^{7}$

With an endogenous labor supply, the "Dutch disease" effects of increased remittances can be exacerbated. An increase in non-labor income, as is the case with remittances, leads to a reduction in the labor supply. In a general equilibrium setting, wages are set to clear the labor market and reduced labor supply implies higher wages. This triggers second order effects: higher wages raise the opportunity cost of leisure and the substitution effect can push individuals to increase their labor supply, up to the point where the income effect dominates (the backward bending labor supply curve). Within a range of reasonable labor supply elasticity values, the new equilibrium will be achieved with a lower labor supply and higher average wages, which translate into higher domestic production costs. Therefore, in

\footnotetext{
${ }^{6}$ Note that the price of leisure is the economy-wide wage rate $W$ (i.e. $P_{0}=W$ ).

${ }^{7}$ This sign ambiguity allows for a backward-bending labor supply curve.
} 
the current model setup the introduction of an endogenous labor supply leads to a further loss in international competitiveness and exacerbates the effects of real exchange rate appreciation described earlier.

\section{B. Jamaican Economy in 2002: Data Sources and Sectoral Structure}

The initial benchmark equilibrium for the CGE model in our study is a 2002 Social Accounting Matrix (SAM), which was constructed specifically for this exercise. ${ }^{8}$ This SAM has been assembled from various sources and includes 22 sectors, 22 commodities, 3 factors (skilled and unskilled labor and one composite capital), an aggregate household account, ${ }^{9}$ and other accounts (government, savings and investment, and the Rest of the World). Macroeconomic and sectoral data come from various publications of the Statistical office of Jamaica (STATIN), while microeconomic data on sectoral employment, wages and household consumption are estimated from the 2002 Labor Force Survey and the 2002 Survey of Living Conditions. International trade data and tariff protection rates are obtained from the UN COMTRADE and TRAINS databases.

The Jamaican economy is dominated by service sectors, which account for more than 80 percent of the GDP at factor cost. ${ }^{10}$ Household consumption consists mainly of food products, where the processed foods and sugar sectors account for 30.5 percent of total. Services account for an additional 35 percent of household consumption, and the rest is spread fairly evenly across the agricultural and manufacturing sectors. Capital goods, chemical products, and refined oil dominate Jamaican imports, with these three sectors accounting for 58 percent of imports at world prices. In value terms, merchandise imports are more than three times the merchandise exports, but the overall trade balance is much less skewed due to large service exports, particularly in the tourism sector. ${ }^{11}$ In fact, while service imports represent only 25 percent of overall imports, service exports are more than twice as large as exports of goods. Nonetheless, Jamaica has a current account deficit with the rest of the world, which is financed by large current and capital financial

\footnotetext{
${ }^{8}$ For more details on the SAM, see the Annex 6.2.

${ }^{9}$ One version of the SAM has two separate household groups defined according to main income source of the household head-see Section IV-D

${ }^{10}$ This figure includes public services in the definition. Private services represent 68 percent of GDP at factor cost (labor and capital value-added).

${ }^{11}$ The tourism sector is part of the "commerce" account in our SAM.
} 
inflows. With only a few exceptions (processed sugar, beverages and tobacco), most sectors are clearly biased towards either exports or imports, making it easier to trace the effects of exchange rate shocks on domestic production and consumption. ${ }^{12}$ In particular, import dependence is very high for most manufacturing sectors. Table 2 Sectoral composition of production, exports, and imports provides additional detail on the structure of the economy and the links between domestic production, exports, and imports.

The government is a relatively small part of the economy: it accounts for approximately 10 percent of employment and just over 13 percent of value added.

Table 2. Sectoral Composition of Production, Exports, and Imports

\begin{tabular}{|c|c|c|c|c|c|c|}
\hline & \multirow{2}{*}{$\begin{array}{c}\text { Contribution } \\
\text { to domestic } \\
\text { production }\end{array}$} & \multirow{2}{*}{$\begin{array}{l}\text { Exports as } \\
\text { a share of } \\
\text { domestic } \\
\text { production }\end{array}$} & \multirow{2}{*}{$\begin{array}{l}\text { Imports as } \\
\text { a share of } \\
\text { domestic } \\
\text { production }\end{array}$} & \multicolumn{3}{|c|}{ Share of total value added } \\
\hline & & & & $\begin{array}{l}\text { Unskilled } \\
\text { Labor }\end{array}$ & $\begin{array}{l}\text { Skilled } \\
\text { Labor }\end{array}$ & Capital \\
\hline Export Crops & 2 & 19 & 5 & 57 & 24 & 19 \\
\hline Food Crops & 2 & 5 & 34 & 53 & 19 & 28 \\
\hline Livestock & 2 & 0 & 1 & 32 & 55 & 13 \\
\hline Forestry and Fishing & 1 & 5 & 107 & 37 & 27 & 36 \\
\hline Mining & 5 & 75 & 8 & 4 & 14 & 82 \\
\hline Food Products & 9 & 3 & 21 & 9 & 30 & 62 \\
\hline Processed Sugar & 1 & 40 & 54 & 30 & 59 & 11 \\
\hline Beverages and Tobacco & 2 & 14 & 14 & 3 & 12 & 86 \\
\hline Textiles and Clothing & 1 & 1 & 29 & 34 & 62 & 4 \\
\hline Wood Products & 1 & 1 & 23 & 27 & 65 & 7 \\
\hline Paper and Print & 1 & 1 & 94 & 5 & 65 & 30 \\
\hline Refined Oil & 3 & 6 & 130 & 8 & 13 & 79 \\
\hline Chemicals & 2 & 16 & 133 & 2 & 24 & 74 \\
\hline Capital Goods & 1 & 24 & 1,284 & 9 & 27 & 64 \\
\hline Electricity and Water & 3 & 0 & 0 & 3 & 19 & 78 \\
\hline Construction & 12 & 0 & 0 & 33 & 28 & 39 \\
\hline Commerce & 20 & 43 & 4 & 13 & 20 & 67 \\
\hline Transport & 12 & 13 & 0 & 16 & 34 & 50 \\
\hline Financial and Insurance Services & 4 & 5 & 26 & 3 & 24 & 72 \\
\hline Real Est. \& Business Services & 5 & 8 & 119 & 18 & 38 & 44 \\
\hline Government Services & 8 & 0 & 0 & 18 & 81 & 1 \\
\hline Other Services & 5 & 1 & 1 & 29 & 52 & 19 \\
\hline
\end{tabular}

\footnotetext{
${ }^{12}$ Although the processed sugar sector has relatively similar export and import intensities, there is virtually no two-way trade in sugar in Jamaica-the exports are composed almost entirely of raw sugar, while the imports come from cane and beet sugar products and molasses.
} 
The government derives approximately 46 percent of its revenues from direct taxes (income taxes and payroll taxes), and the rest from sales taxes, taxes on international trade, and production taxes. Tariff revenue is 27 percent of total tax receipts, and tariff rates are roughly uniform across various trading partners. Interest payments on both domestic and external debt are a large item in the public budgetary accounts; in fact, interest expenditure is one and a half times the public spending on wages and salaries. Therefore, the large interest obligations are a severe constraint on the Jamaican fiscal space and limit the fiscal policy options available to the government.

Another important constraint is related to the real exchange rate volatility. To achieve single digit inflation rates, Jamaican monetary authorities adopted a tight monetary policy consisting of maintaining a stable exchange rate to anchor inflation expectations. This policy has reached its objective and inflation has been reduced from levels well above $30 \%$ in the mid 1990s to less than $10 \%$ in recent years. However, for the period 1996-2001, the policy has also induced a cumulative $30 \%$ real exchange rate appreciation and real interest rates have on average been around 10\%: this combination of loss of competitiveness and high interest rates has contributed to low growth rates.

\section{Remittances, Labor Supply, and the Jamaican Economy: A Numerical Analysis of Their Interdependence and an Assessment of Policy Options}

Using the CGE model described earlier, this section offers an empirical estimate of the economy-wide consequences of an exogenous increase in remittance inflows and an assessment of a specific policy response that minimizes the negative effects of remittances on the labor supply. The policy response consists of a contemporary reduction in payroll taxes and an increase in sales taxes, i.e. a partial switch from direct taxes to indirect taxes. Taxing remittances directly is not a viable policy option for at least two reasons. First, income generating the remittances has already been taxed at the origin and double taxation would increase the agents' incentives to transfer money through the black market. Second, remittances are an important source of household income and taxing them could increase the vulnerability of households to income shocks. An alternative policy tool to limit the negative labor supply response is a reduction in payroll taxes. From the workers' point of view, lower payroll taxes provide greater incentives to work through higher wages. This 
policy also reduces the wages paid by the employers and thereby increases their labor demand. ${ }^{13}$

The following discussion presents a set of simulations that address the above issues in more detail. In the first simulation, remittances rise by 10 percent relative to their 2002 level. ${ }^{14}$ Then, the government responds by reducing payroll taxes by an amount sufficient to return the labor supply to its original level. In order to neutralize the effects of this policy on the budget deficit, the loss in fiscal revenue is offset through a compensating increase in sales tax rates. ${ }^{15}$ Finally, we test the robustness of our estimates with alternative assumptions about the distribution of income and remittances across households and the incidence of payroll taxes.

\section{A. Increased Remittance Inflows}

We begin by analyzing the macroeconomic effects of the remittance shock, which are shown in the first column of Table 3 Macroeconomic results. Since the current account is fixed by the available quantity of foreign saving, increased remittances allow import volumes to rise without a corresponding increase in export volumes. Due to higher income from additional remittances, households demand more goods and services and consumption rises by 1.5 percent relative to the initial equilibrium. On the other hand, domestic output, proxied by real GDP, falls by 0.4 percent. The reasons for this decline in output follow the discussion in section Modeling economy-wide effects of increased remittance inflows. First, increased demand for Armington goods drives up domestic prices and hurts the sales of both export-oriented and import-competing activities. Second, labor supply declines as households consume more leisure, which results in higher wages, higher production costs, and further loss of competitiveness with the foreignproduced goods. This erosion of competitiveness is summarized by the 0.9 percent appreciation in the real exchange rate. ${ }^{16}$

\footnotetext{
${ }^{13}$ This simulation should be considered as illustrative for any set of policies aiming at reducing the wedge between wages paid by the employers and those received by the workers. The current simulation assumes that the government is directly able to reduce this wedge by reducing a payroll tax; however the actual fiscal instruments at the government disposal may be less direct, and revenues from payroll taxes may not be easily substituted by revenues from other taxes. ${ }^{14}$ This increase in remittance inflows is not very large considering the rapid pace of remittance growth
over the last decade (see section II).

${ }^{15}$ In all simulations, the real level of government expenditure is held constant.
} 
Table 3. Macroeconomic Results

\begin{tabular}{lccc}
\hline & $\begin{array}{c}\text { Remittance effect, } \\
\text { percent change } \\
\text { from baseline }\end{array}$ & $\begin{array}{c}\text { Tax effect, per- } \\
\text { cent change from cent change from } \\
\text { remittance shock }\end{array}$ & $\begin{array}{c}\text { Total effect, per- } \\
\text { baseline }\end{array}$ \\
\hline Remittances & 10.00 & 0.00 & 10.00 \\
Real exchange rate & 0.88 & -0.23 & 0.64 \\
Real GDP & -0.37 & 0.24 & -0.13 \\
Private consumption & 1.48 & 0.80 & 2.29 \\
Exports & -2.70 & 0.41 & -2.30 \\
Imports & 0.82 & 0.11 & 0.93 \\
Unskilled wage & 2.30 & 2.48 & 4.84 \\
Skilled wage & 2.25 & 2.40 & 4.70 \\
Absolute change in unskilled labor supply & $-3,821$ & 3,821 & 0 \\
Absolute change in skilled labor supply & $-4,552$ & 3,442 & $-1,111$ \\
\hline
\end{tabular}

The effect of increased remittances on wages and labor supply is comprised of two components: on the one hand, labor supply declines because more non-labor income encourages households to consume more leisure, but on the other hand, reduced labor supply is accompanied by increased labor demand (given the increased demand for goods) and wages rise. The wage increase adds second-order effects to the change in labor supply, since an increase in the wage rate raises the opportunity cost of leisure and, as long as the substitution effect dominates the income effect, encourages households to supply more labor. ${ }^{17}$ In the final equilibrium, wages for both skilled and unskilled workers are indeed higher by approximately 2.3 percent relative to the base case, but this increase is not enough to offset the initial contraction in the labor supply and the quantity of workers is lower by 8,374 persons (just under one percent of initial employment). ${ }^{18}$ Although the change is small in aggregate terms, consider that this reduction is equivalent to the total number of people employed in a sector such as mining or processed sugar.

Although the decline in GDP is modest, larger variations are observed at the sectoral level. The impact of the shock is determined by the different trade orientation

\footnotetext{
${ }^{16} \mathrm{We}$ use the deflator of GDP at factor cost as a measure of the real exchange rate. This definition is appropriate because GDP at factor cost is composed of inputs that are truly non-tradable. Note that the tables report an inverse quote of the exchange rate: an increase implies appreciation.

${ }^{17}$ See equations (4) and (5) above.

${ }^{18}$ Given that skilled and unskilled workers are employed with different intensities across sectors and that final demand does not increase equally for all goods and services, the general equilibrium effects will differ across the types of workers.
} 
of each sector (which can be more or less import competing, export oriented or nontraded) as well as by their different factor intensities (see Table 2). The first four columns of Table 4 show the disaggregate results-percentage changes in sectoral exports, imports, production, and private consumption-following the remittance shock. On the demand side, changes are driven by different income elasticities across goods: while food and agricultural products are necessities and therefore have income elasticities below one, the income elasticities of manufactured goods and services are higher. On the supply side, sectors that experience the greatest decline in production are either export intensive (e.g., mining, processed sugar, and commerce) or import competing (e.g., capital goods, business services, and refined oil). This response is a direct consequence of the Dutch disease effect observed at the aggregate level. Among sectors facing comparable import competition, those using labor more intensively than capital suffer more pronounced output losses. This is a consequence of the shrinking labor supply which makes capital relatively more abundant and thus less costly relative to labor. ${ }^{19}$

Other sectors with high shares of labor in total value added, such as livestock and textiles, are able to increase production in the face of higher labor costs. This result can be explained by two reasons. First, most of the production in these sectors is sold domestically and there is very little competition from imports. This situation 'protects' these sectors from the effects of the real exchange rate appreciation: due to the limited substitution across domestic and imported goods, the additional demand generated by the remittance shock is mainly satisfied through larger domestic supply, even if relative prices (of domestic varieties versus imported ones) worsen. A second reason explaining output expansion is the fact that although labor costs go up, non-labor costs go down. Production in sectors such as livestock and textiles requires a large amount of intermediate inputs that tend to be imported and thus become cheaper with a real exchange rate appreciation. ${ }^{20}$

\section{B. Public Policies to Neutralize Labor Supply Reductions}

In the second simulation, the government sterilizes the remittance-induced

\footnotetext{
${ }^{19}$ These effects are shown in Table 4 Sectoral results where production in sectors that demand a lot of labor, such as export crops, food crops, and processed sugar, experiences larger declines.

${ }^{20}$ Labor is a large share of total value added and labor costs rise substantially: the price of the labor-capital bundle for livestock and textiles rises by 1.9 and 2.2 percent, respectively. However, due to the described savings on imported intermediaries, the increase in the total cost of production is less severe: producer prices increase by 0.9 and 0.6 percent.
} 
Table 4. Sectoral Results

\begin{tabular}{|c|c|c|c|c|c|c|c|c|c|c|c|c|}
\hline & \multicolumn{4}{|c|}{$\begin{array}{l}\text { Remittance effect, percent change } \\
\text { from baseline }\end{array}$} & \multicolumn{4}{|c|}{$\begin{array}{l}\text { Tax effect, percent change } \\
\text { from remittance shock }\end{array}$} & \multicolumn{4}{|c|}{$\begin{array}{l}\text { Total effect, percent change } \\
\text { from baseline }\end{array}$} \\
\hline & $\mathrm{X}$ & $\mathrm{M}$ & $\mathrm{P}$ & $\mathrm{C}$ & $X$ & $\mathrm{M}$ & $\mathrm{P}$ & $\mathrm{C}$ & $\mathrm{X}$ & $\mathrm{M}$ & $\mathrm{P}$ & $\mathrm{C}$ \\
\hline Export Crops & -3.46 & 2.91 & -0.53 & 1.09 & 1.75 & 0.17 & 1.01 & 0.44 & -1.8 & 3.1 & 0.5 & 1.5 \\
\hline Food Crops & -4.86 & 3.46 & -0.42 & 1.05 & 2.38 & -0.02 & 1.07 & 0.67 & -2.6 & 3.4 & 0.6 & 1.7 \\
\hline Livestock & -2.74 & 3.25 & 0.64 & & 1.76 & 0.20 & 0.86 & & -1.0 & 3.5 & 1.5 & \\
\hline Forestry and Fishing & -2.53 & 2.29 & 0.05 & 1.41 & 1.82 & 0.64 & 1.18 & 0.88 & -0.8 & 2.9 & 1.2 & 2.3 \\
\hline Mining & -2.99 & 1.61 & -2.33 & 1.28 & -0.14 & 0.80 & 0.00 & 1.00 & -3.1 & 2.4 & -2.3 & 2.3 \\
\hline Food Products & -1.55 & 2.59 & 0.72 & 1.18 & 1.34 & 0.49 & 0.87 & 0.79 & -0.2 & 3.1 & 1.6 & 2.0 \\
\hline Processed Sugar & -5.85 & 3.32 & -2.78 & 1.37 & 2.72 & 0.30 & 1.87 & 1.04 & -3.3 & 3.6 & -1.0 & 2.4 \\
\hline Beverages and Tobacco & 0.79 & 0.08 & 0.44 & 2.03 & -0.46 & 0.70 & 0.11 & 0.17 & 0.3 & 0.8 & 0.6 & 2.2 \\
\hline Textiles and Clothing & -1.26 & 2.83 & 1.05 & 1.65 & 1.80 & 0.96 & 1.32 & 1.29 & 0.5 & 3.8 & 2.4 & 3.0 \\
\hline Wood Products & -2.40 & 1.77 & -0.07 & 1.66 & 0.89 & -0.22 & 0.26 & 1.09 & -1.5 & 1.5 & 0.2 & 2.8 \\
\hline Paper and Print & -3.12 & 1.44 & -0.56 & 1.76 & 1.72 & 0.55 & 1.06 & 1.18 & -1.5 & 2.0 & 0.5 & 3.0 \\
\hline Refined Oil & -1.90 & -0.01 & -0.89 & 1.88 & -0.15 & 0.42 & 0.16 & 0.85 & -2.1 & 0.4 & -0.7 & 2.8 \\
\hline Chemicals & -1.84 & 1.53 & -0.23 & 1.75 & 1.37 & 0.90 & 1.14 & 1.25 & -0.5 & 2.4 & 0.9 & 3.0 \\
\hline Capital Goods & -2.97 & 0.18 & -1.61 & 1.93 & 0.02 & -0.38 & -0.15 & 1.32 & -2.9 & -0.2 & -1.8 & 3.3 \\
\hline Electricity and Water & -0.21 & & 0.20 & 1.90 & 0.28 & & 0.51 & 0.39 & 0.1 & & 0.7 & 2.3 \\
\hline Construction & & & -0.14 & & & & -0.93 & & & & -1.1 & \\
\hline Commerce & -2.58 & 1.83 & -1.15 & 1.81 & 0.33 & -0.20 & 0.15 & 0.20 & -2.3 & 1.6 & -1.0 & 2.0 \\
\hline Transport & -2.49 & & -0.36 & 1.70 & 0.88 & & 0.41 & 0.32 & -1.6 & & 0.1 & 2.0 \\
\hline Financial and Insurance Services & -0.64 & 0.96 & 0.22 & 2.16 & 0.40 & 0.51 & 0.46 & 0.59 & -0.2 & 1.5 & 0.7 & 2.8 \\
\hline Real Est. \& Business Services & -4.76 & 0.76 & -1.91 & 2.01 & 1.57 & 0.12 & 0.80 & 1.26 & -3.3 & 0.9 & -1.1 & 3.3 \\
\hline Government Services & & & -0.01 & 0.86 & & & 0.04 & 0.51 & & & 0.0 & 1.4 \\
\hline Other Services & -4.00 & 4.61 & 0.78 & 1.17 & 2.31 & -0.35 & 0.80 & 0.84 & -1.8 & 4.2 & 1.6 & 2.0 \\
\hline
\end{tabular}


reduction in the labor supply by a reduction in the payroll tax rate, which is paid by workers in both skill categories and in all sectors. ${ }^{21}$ The payroll tax rate is reduced in a uniform fashion to ensure that the unskilled labor supply returns to its initial (pre-remittance shock) level. In the absence of other policies, this would lead to increased fiscal deficit, which is a major cause for concern due to the heavy public debt burden. To neutralize the undesirable effects on public saving and investment, sales tax rates are allowed to vary so that the government savings are maintained at the initial equilibrium level. Sales taxes affect consumption choices and should be preferred to direct increases of income taxes, which could potentially deter future or even current flows of remittances. Increasing taxes on international trade is not recommendable, since protectionism is likely to reduce welfare at home.

The starting point for this simulation is the equilibrium attained after the 10 percent remittance shock, and the results, as percentage changes from that previous simulation, are presented in the second column of Table 3. The third column of this table contains the cumulative change from the initial equilibrium (i.e., the total effect of the remittance shock and the policy response). The reduction in payroll taxes increases after-tax wages while lowering firm labor costs (gross wages). In this situation, households choose to reduce their consumption of more expensive leisure and increase their labor supply. In order to fully offset the initial decrease in unskilled labor supply, the payroll tax rate declines from 10 percent to 6.6 percent; this also neutralizes 76 percent of the initial decline in the supply of skilled labor. As a result, output rises by 0.24 percent, making up approximately two-thirds of production losses in the previous simulation. This increase in domestic production is accompanied by real exchange depreciation, which signals an improvement in international competitiveness. This is a direct consequence of lower labor costs through reduced wage taxes: gross wages paid to skilled and unskilled workers decline by 0.8 and 0.7 percent, respectively. This improvement in competitiveness is further aided by a change in the tax structure, since indirect taxes are not collected on exports and therefore the tax policy switch acts as an export subsidy. The policy response allows the domestic producers to re-coup some of the export losses observed in the previous simulation. However, since the current account deficit is fixed, the trade balance remains unchanged from the earlier scenario.

The total change in consumption is an outcome of two offsetting trends. On the one hand, due to increased labor force participation and higher wages, household

\footnotetext{
${ }^{21}$ The implications of relaxing this assumption are investigated in section IV-C below.
} 
labor income rises by 2.8 percent, with a cumulative increase of 4.3 percent after both simulations. On the other hand, the sales tax rate (which is assessed only on final goods) has to rise by 47 percent in order to keep the public deficit constant. Although the relative magnitude is large, the initial sales tax rates are fairly low, which cushions some of the impact on consumers. For example, the sales tax rate on food products (the biggest consumption category) increases from 1.3 percent to 1.9 percent. In total, consumption increases by 0.8 percent, about one-half of the increase that could be expected without an offsetting rise in indirect taxes (i.e., if budget deficit was not fixed).

The switch from direct (payroll) to indirect (sales) taxation is accompanied by increases in the tax base for both policy instruments. The sales tax revenue rises by 49 percent with a 47 percent increase in the tax rate, while direct tax revenue falls by 32 percent with a 34 percent decline in the corresponding tax rate. For the payroll tax, the increased income is mainly the result of higher wage for both skill categories, while the indirect tax revenues are bolstered by higher domestic demand.

The sectoral results of the tax cut and the cumulative effects of the first two simulations are summarized in the rightmost eight columns of Table 4. Due to higher income, the majority of goods and services register a cumulative total increase in consumption demand of 2 percent or more, with some variation due to different income elasticities. Production increases in two-thirds of all sectors, while the output of more capital intensive sectors declines. This is due to the fact that capital, having become scarcer (following the increase in labor supply), receives higher rent.

\section{Sensitivity Analysis: the Incidence of Payroll Taxes and Remittances}

The analysis and policy advice in the two previous sections depend on some key assumptions and parameters of the model. Three are particularly important: the assumption that all workers contribute to the payroll tax, the assumption that all households receive remittance income, and the values of the elasticity of substitution between capital and labor and between different types of labor. This section considers the consequences of changes to these important model elements by implementing a set of alternative simulations. In the first scenario, we assume that only the skilled workers, whose average wage is 82 percent above the unskilled average wage, pay the payroll tax. In the second scenario, we split households into two separate groups - those earning income from skilled and unskilled labor-and allow the unskilled household to be the sole beneficiary of remittance flows. 
Finally, we implement a series of scenarios that capture the impact of a wide range of elasticity values on the key model results.

The results of the first simulation are summarized in Table 5. The numbers in the first column of the table (effects of the remittance shock) are identical to those in Table 3 Macroeconomic results and do not warrant further explanation. In order to facilitate comparisons with the tax scenario in the previous section, the payroll tax rate is reduced by exactly the same amount as before and therefore the compensating increase in sales taxes is nearly identical. The changes in main macroeconomic variables - real GDP, consumption, exports, imports, and the real exchange rateare very close to those recorded in Table 3 . The underlying behavior of the labor markets, however, is quite different. The current simulation maintains the same structure of the public budget as scenarios in the previous section, which implies that the payroll tax rates paid by skilled workers are much higher than before (because the tax base is smaller). Therefore, the payroll tax reduction has a larger initial impact on wages and encourages a greater quantity of skilled workers to return to the labor force (more than double the previous amount). At the same time, firms' costs of hiring skilled workers also experience a more pronounced decline, which increases the demand for skilled labor but also reduces demand for unskilled workers, who are now relatively more expensive. This causes unskilled workers to exit the labor market, which prevents their wage rate from declining with respect to the remittance shock. The final equilibrium is achieved at a significantly lower unskilled employment level, which declines by an additional 0.4 percent from the remittance shock and brings the total contraction to 1.2 percent of unskilled

Table 5. Macroeconomic Results with Payroll Tax Levied Exclusively on Skilled Workers

\begin{tabular}{lccc}
\hline & $\begin{array}{c}\text { Remittance effect,Tax effect, percent } \\
\text { percent change } \\
\text { from baseline } \\
\text { change from } \\
\text { remittance shock }\end{array}$ & $\begin{array}{c}\text { Total effect, } \\
\text { percent change } \\
\text { from baseline }\end{array}$ \\
\hline Remittances & 10.00 & 0.00 & 10.00 \\
Real exchange rate & 0.88 & -0.21 & 0.67 \\
\hline Real GDP & -0.37 & 0.22 & -0.15 \\
Private consumption & 1.48 & 0.78 & 2.27 \\
Exports & -2.70 & 0.38 & -2.33 \\
Imports & 0.82 & 0.10 & 0.92 \\
\hline Unskilled wage & 2.31 & 1.70 & 4.04 \\
Skilled wage & 2.25 & 2.99 & 5.31 \\
Absolute change in unskilled labor supply & $-3,822$ & $-2,062$ & $-5,884$ \\
Absolute change in skilled labor supply & $-4,553$ & 8,749 & 4,196 \\
\hline
\end{tabular}


employment in the baseline. The reduction is partially compensated by a much stronger response in skilled employment, which actually rises by 0.8 percent relative to the baseline, although total employment still falls by 1,689 persons, 578 people more than in the previous scenario. This shows that the tax switching policy is less effective at stimulating employment when the incidence of the payroll tax falls squarely on the skilled workers. At the same time, the policy remains just as effective at promoting competitiveness and increasing output because the final difference in employment is quite small and skilled workers are more productive than the unskilled.

Before implementing the second simulation, we conduct some preliminary analysis using the combined data from the 2002 Labor Force Survey and the 2002 Survey of Living Conditions in order to better understand the distribution of remittance income across different groups of households. We find that households where the head is unemployed are 10 percent more likely to report remittance income, and households where the head is outside the labor force are 20 percent more likely to report remittance income (see Table 6). In both agriculture and services, one-fifth of households report remittance income, while for households where the head is employed in manufacturing that share is 16 percent.

Households with a more educated head are much less likely to receive remittances than households where the head has completed less than secondary school: 20 percent of households with a less educated head report some remittance income, while only 13 percent of households with a more educated head do so. However, the difference is much less clear if occupation instead of education level

Table 6. Distribution of Remittance Income

\begin{tabular}{lrccr}
\hline Number of households who receive remittances & All & Share (\%) & \\
& Recipients & $\begin{array}{c}\text { All } \\
\text { households }\end{array}$ & & \\
\hline Employed & 707 & 3534 & 20 & \\
Unemployed & 78 & 338 & 23 & \\
Inactive & 323 & 1258 & 26 & \\
Total & 1,108 & 5,130 & 22 & \\
\hline Distribution of households who report remittance income (percent) & \\
Education / Sector of employment & Agriculture & Manufacturing & Services & Total \\
\hline Completed primary & 33.1 & 5.4 & 60.2 & 98.8 \\
Completed secondary or higher & 0.0 & 0.0 & 1.2 & 1.2 \\
Total & 33.1 & 5.4 & 61.5 & 100.0 \\
\hline
\end{tabular}


is used as a proxy for human capital. Remittances are a key source of income: they represent on average 82 percent of total income for the group of households reporting receipts of these inflows. For this group, the distribution of remittances according to education level and sector of employment is shown in the bottom part of Table 6 Distribution of remittance income.

To accommodate this evidence of a bias in the distribution of remittances receipts towards unskilled headed households, we disaggregate the households in two groups: households receiving labor income exclusively from unskilled workers and household receiving labor income from skilled workers. Remittances are then received only by the first group. Other sources of income (from capital and other transfers) are disaggregated proportionally between the two groups. Since in reality, most households receive labor income from both types of workers, the described set up represents an extreme segmentation of income sources across household types and the results derived from it should be considered illustrative and should provide a useful contrast to those shown in the previous sections.

The results of a revenue-neutral decrease in payroll taxes under the setup described in the previous paragraph are shown in Table 7. For the unskilled household, remittances represent a much larger share of total income (35 percent) than for the average household considered in the previous section (15 percent), which implies that the initial contraction in the labor supply is much more pronounced. However, the reduction in labor supply is limited to unskilled workers, while the supply of skilled workers rises by 0.3 percent relative to the baseline. This increase is determined by two factors. First, the contraction in unskilled labor supply drives up the wage costs for this worker category and encourages firms to substitute towards a more skill-intensive labor mix. Second, rental rates on capital fall due to increased competition from imports and lead to lower incomes of skilled-headed households. ${ }^{22}$ To compensate for this loss, skilled households further increase their labor supply; the total expansion more than offsets the increase in labor demand and causes the slight reduction in skilled wages recorded in Table 7.

Despite the fact that the contraction in total labor supply is 10 percent larger than in the results shown in Table 3 Macroeconomic results, the loss in output and real

\footnotetext{
${ }^{22}$ Capital income decreases due to the reallocation of resources set in motion by the real exchange rate appreciation. Importable sectors are especially capital intensive and increased flows of imports cause these sector to shrink and to release capital. Thus, rental rates have to go down so that idle capital can be employed in other sectors.
} 
Table 7. Macroeconomic Results with Remittances Accruing only to Unskilled-headed Household

\begin{tabular}{lccc}
\hline & $\begin{array}{c}\text { Remittance effect, } \\
\text { percent change } \\
\text { from baseline }\end{array}$ & $\begin{array}{c}\text { Tax effect, percent } \\
\text { change from } \\
\text { remittance shock }\end{array}$ & $\begin{array}{c}\text { Total effect, } \\
\text { percent change } \\
\text { from baseline }\end{array}$ \\
\hline Remittances to unskilled headed hh & 10.00 & 0.00 & 10.00 \\
Remittances to skilled headed hh & 0.00 & 0.00 & 0.00 \\
Real exchange rate & 0.67 & -0.19 & 0.48 \\
\hline Real GDP & -0.23 & 0.21 & -0.02 \\
Private consumption & 1.51 & 0.80 & 2.32 \\
Exports & -2.41 & 0.35 & -2.07 \\
Imports & 0.82 & 0.11 & 0.93 \\
\hline Unskilled wage & 5.14 & 1.89 & 7.12 \\
Skilled wage & -0.17 & 2.92 & 2.74 \\
Absolute change in unskilled labor supply & $-11,002$ & 5,281 & $-5,721$ \\
Absolute change in skilled labor supply & 1,823 & 2,110 & 3,933 \\
\hline
\end{tabular}

exchange rate appreciation are less pronounced than before. This happens because the labor supply reduction affects only the unskilled workers, whose contribution to the average wage is smaller than their share of total employment. As a result, the economy-wide average wage rises by less than before ( 2.0 percent vs. 2.3 percent), moderating the increase in domestic production costs and therefore limiting the appreciation of the real exchange rage.

To facilitate comparability with earlier scenarios, the government lowers the payroll tax rate by 34 percent, the same reduction as in the previous section. This is sufficient to neutralize approximately one-half of the initial contraction in unskilled labor supply and encourages even more skilled workers to enter the labor force. ${ }^{23}$ The total reduction in labor supply is 1,788 workers, which is 60 percent larger than the total decline recorded in Table 3. However, since the decrease is due entirely to the contraction in unskilled workers (unlike skilled labor in Table 3) whose contribution to a unit of output is below that of skilled workers, the increase in output and improvement in competitiveness as a result of tax policy are similar to before.

The impact of choosing alternative values for the elasticity of substitution between capital and labor is shown in Figure 2. The default value of the elasticity of substitution between these two factors (as well as the elasticity of substitution

\footnotetext{
${ }^{23}$ In order to fully neutralize the original contraction in unskilled labor supply, the payroll tax rate would have to be reduced by 70 percent.
} 
Figure 2. Impact of Alternative Elasticity Values on Changes in Real GDP and Real Exchange Rate

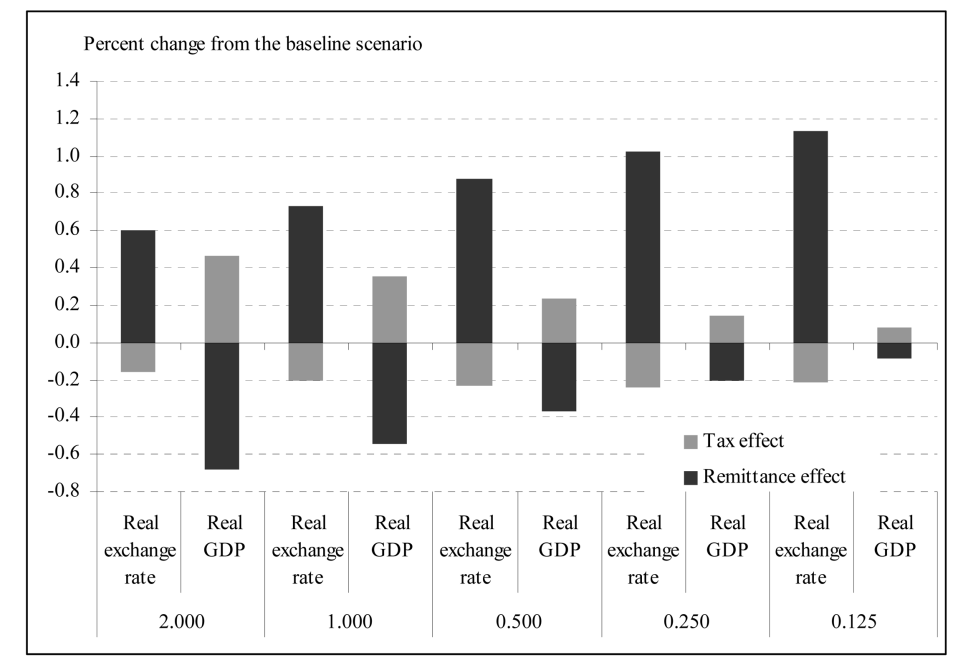

Note: The figure shows the impact of re-calibrating and re-running the model with a range of values for the elasticity of substitution between capital and labor. The elasticity values are listed in the last row of the horizontal axis title, with 0.5 the default (standard) elasticity.

between skilled and unskilled labor) is 0.5, drawn from a set of standard elasticities for the World Bank's global LINKAGE model (van der Mensbrugghe, 2005). A decrease in the elasticity of substitution between capital and labor increases the upward pressure on wages after the remittance shock (as firms find it more difficult to replace workers with machinery) and therefore encourages more workers to reenter the labor force. In other words, lower capital-labor substitution elasticity magnifies the substitution effect in the labor supply decision. This lowers the real GDP penalty of a reduced labor force, but also magnifies the real exchange rate appreciation due to higher wage costs. In the policy response scenario, a lower elasticity value similarly limits the positive impact on real GDP and the reduction in domestic production costs. However, even with elasticity values ranging from 1/4 to 4 times the default value, the qualitative conclusions and policy recommendations of the previous sections remain valid. The remittance-induced real exchange rate appreciation is magnified when leisure is introduced in the individual's utility function, and the policy response of switching towards indirect taxation helps to offset both the decline in real GDP and the loss in export competitiveness caused by Dutch disease. 


\section{Conclusions}

In this paper, we investigate the economy-wide effects of rising remittances for Jamaica using a general equilibrium model with an endogenous labor supply that responds negatively to increases in non-wage income. Our numerical estimations are based on a recent (2002) Social Accounting Matrix for Jamaica and on the household survey evidence of the negative relationship between labor supply and remittances (Kim, 2006). The data included in the SAM are derived from heterogeneous sources, some of which are quite dated. Although we use sophisticated 'data-updating' statistical procedures, the final result could be improved once new data are collected and made available. Similarly, the econometric evidence on the negative labor supply - remittances relationship is not very strong. These limitations, common to most numerical simulation exercises, highlight the fact that our results should be considered as just a coherent and informed illustration of the direction and magnitude of the effects of rising remittances on the Jamaican economy, rather than as a forecast of what will happen in the country.

Nonetheless, some interesting lessons can still be learned from this exercise. Firstly, a small positive shock to remittance inflows can have relevant economywide repercussions. By reducing labor force participation and thus increasing wages, this shock exacerbates the appreciation of the real exchange rate, reducing the country's competitiveness on the international markets. Second, within the narrow margins of maneuver of a highly indebted government, a revenue-neutral policy response that reduces labor costs - via a reduction in payroll taxes and a compensating increase in sales tax rates-can effectively counteract the negative effects of remittance inflows.

Sensitivity analysis shows that considering the identities of the beneficiaries of remittances as well as the incidence of the payroll tax matter for the final results. If remittances accrue only to unskilled headed households or if the payroll tax is paid exclusively by higher-paid skilled workers, the labor market effects are more complex and the corrective policy less effective. This clearly signals the need for additional research aimed at better understanding these distributional effects. At the same time, the policy of switching from direct to indirect taxation in all cases remains effective at counteracting the negative effects of increased remittances on output and international competitiveness (real exchange rate). Furthermore, despite the lack of dynamics in our model, this result is consistent with findings from forward-looking real business cycle (RBC) models, such as the dynamic stochastic 
general equilibrium (DSGE) model of Chami et al. (2006). ${ }^{24}$

The above results come with an important set of caveats. First, one should note that although remittances have some undesirable effects on Jamaica's competitiveness and labor force participation, they are not themselves undesirable. In fact, remittances represent an important channel of external financing for the economy as a whole, and they also account for a large share of the income of unskilled and unemployed/inactive individuals, who are more likely to be poor. Similarly, while the reduction in labor supply by the remittance recipients has some negative consequences, the decision itself is utility-maximizing. Therefore, the optimal policy response should focus on minimizing the negative indirect impacts rather than minimizing remittances themselves (for example, by taxing them directly).

Second, our estimates and the policy recommendations that they underpin only partially take into account the informal sector in Jamaica, estimated at 40-44 percent of the official GDP in 2001 (IADB, 2006). It is difficult to assess the bias in our estimates for a number of reasons, including combining different data sources (e.g., expenditure data are based on official national accounts which largely ignore the informal sector, while the employment data include informal workers) and varying definitions of informality (e.g., the IADB (2006) study states that 30 percent of informal workers have formal employment contracts). However, the results of the first sensitivity scenario of this paper-where only the skilled workers pay the wage tax - show that the policy recommendations remain valid even if just one-half of the employed are subject to the payroll tax.

Third, it should be acknowledged that a move towards more indirect taxation may have some adverse consequences by shifting the tax burden on the poorer households. Although the changes in tax structure implied by our results are mild and the policy is beneficial for the economy as a whole, there may be a need for actions to smooth the transition for the most vulnerable parts of the population.

\section{Acknowledgements}

We are grateful to Errol Graham, Pedro Olinto, Hans Timmer, Dominique van der Mensbrugghe, the editors, two anonymous referees, participants of the 2007

\footnotetext{
${ }^{24}$ Chami et al. (2006) find that in the presence of remittances, monetary policy is forced to deviate from the Friedman rule if taxes are levied on labor income, but optimal policy may be restored if the government is able to introduce or adjust a tax on consumption.
} 
GTAP conference at Purdue University, and participants of the 2007 LACEA conference at the Universidad de los Andes for useful comments and suggestions. We also thank Sudhanshu Handa and Damien King for sharing key data.

Received 30 June 2007, Revised 7 March 2008, Accepted 8 April 2008

\section{References}

Amuedo-Dorantes, C., Pozo, S. (2005) International Remittances and Their Employment Implications in Receiving Areas, Preliminary Draft of Paper Prepared for the 2005 SOLE/EALE Conference Meeting.

Annabi, N. 2003. Modeling Labor Markets in CGE Models: Endogenous Labor Supply, Unions, and Efficiency Wages, Poverty and Economic Policy (PEP) Network Working Paper, May.

Barzel, Y., McDonald, R. (1973) Assets, Subsistence, and the Supply Curve of Labor, American Economic Review 63(4), pp. 621-633.

Botero, J., Djankov S., La Porta R., Lopez-de-Silanes, F., Shleifer, A. (2004) The Regulation of Labor, Quarterly Journal of Economics 119, pp. 1339-1382.

Burnside, C., Dollar, D. (2002) Aid, Policies, and Growth, American Economic Review 90(4), pp. 847-68.

Chami, R., Cosimano, T., Gapen, M. (2006) Beware of Emigrants Bearing Gifts: Optimal Fiscal and Monetary Policy in the Presence of Remittances, IMF Working Paper No. 06/61, March.

Collier, P., Dollar, D. (2002) Aid Allocation and Poverty Reduction, European Economic Review 46 (8), pp. 1475-500.

Connell, J., Brown, R. (2005) Remittances in the Pacific: An Overview, Asian Development Bank.

De Melo, J., Tarr, D. (1992) General Equilibrium Analysis of US Foreign Trade Policy, Cambridge, Mass.: MIT Press.

Downes, A., Mamingi, N., Belle Antoine, R. (2000) Labor Market Regulation and Employment in the Caribbean, Inter-American Development Bank Research Network Working Paper \#R-388, April.

Forteza, A., Rama, M. (2001) Labor Market 'Rigidity' and the Success of Economic Reforms across More than 100 Countries, Policy Research Working Paper 2521. World Bank, Washington, D.C.

Funkhouser, E. (1992) Migration from Nicaragua: Some Recent Evidence World Development, 20(8), pp. 1209-18.

Heckman, J., Pages, C. (2003) Law and Employment: Lessons from Latin America and the Caribbean, NBER Working Papers 10129, National Bureau of Economic Research, Inc.

Inter-American Development Bank (IADB), (2006) The Informal Sector in Jamaica, 
Economic and Sector Study RE3-06-010, December.

International Monetary Fund (IMF) (2004a) Jamaica: 2003 Article IV Consultation-

Staff Report; Staff Statement; Public Information Notice on the Executive Board Discussion; and Statement by the Executive Director for Jamaica, IMF Country Report 04/76, March.

International Monetary Fund (IMF) (2004b) Jamaica: 2004 Article IV ConsultationStaff Report; Public Information Notice on the Executive Board Discussion; and Statement by the Executive Director for Jamaica, IMF Country Report 04/263, August.

Kim, N. (2006) Impact of Remittances on Labor Supply: The Case of Jamaica World Bank Policy Research Working Paper 4120.

Matshe, I., Young, T. (2004) Off-Farm Labour Allocation Decisions in Small-Scale Rural Households, Zimbabwe Agricultural Economics, 30, 2004, pp. 175-186.

Mishra, Prachi, (2006) "Emigration and Wages in Source Countries: Evidence from Mexico", IMF Working Paper WP/06/86, March.

Rodriguez, E., Tiongson, E. (2001) Temporary Migration Overseas and Household Labor Supply: Evidence, Urban Philippines International Migration Review, 2001, pp. 708725.

van der Mensbrugghe, Dominique, (2005) "LINKAGE Technical Reference Document." Mimeo, World Bank, December.

World Bank (2006a) Jamaica Poverty Assessment: Breaking the Cycle of Unemployment, Vulnerability, and Crime, Washington, DC: World Bank.

World Bank (2006b) The Development Impact of Workers' Remittances in Latin America, Washington, DC: World Bank.

\section{Annex}

\section{A. Initial Benchmark Data: the 2002 Jamaica SAM}

The 2002 SAM has been assembled from various sources and includes 22 sectors, 22 commodities, 3 factors (skilled and unskilled labor and composite capital), an aggregate household account, government, savings-investment, taxes, tariffs, and the rest of the world (see Table 8). In order to construct this SAM, we relied on published STATIN data (national accounts and disaggregated GDP by sector), a 2000 SAM for Jamaica constructed by International Food Policy Research Institute (IFPRI), the 2002 Labor Force Survey, the 2002 Survey of Living Conditions, and the UN COMTRADE and TRAINS databases.

Macro SAM. In order to build the macroeconomic SAM, we relied mainly on the national accounts data from STATIN. We have followed this sectoral detail with one exception: we have aggregated "other manufacturing"- a very small 
Table 8. List of Accounts for Jamaica SAM (2002)

\begin{tabular}{ll}
\hline Production sectors and Commodities & Factors of Production \\
\hline 1 Export Crops & 23 Skilled Labor \\
2 Food Crops & 24 Unskilled Labor \\
3 Livestock & 25 Capital and Land \\
\cline { 2 - 2 } 4 Forestry Fishing & Institutions and other accounts \\
\cline { 2 - 2 } 5 Mining & 26 Household \\
6 Food Products & 27 Government \\
7 Processed Sugar & 28 Investment and Savings \\
8 Beverages and Tobacco & 29 Indirect taxes \\
9 Textiles and Clothing & 30 Tariffs \\
10 Wood Products & 31 USA \\
11 Paper and Print & 32 European Union \\
12 Refined Oil & 33 Rest of the World \\
13 Chemicals & 34 Balance of Payment \\
14 Capital Goods & \\
15 Electricity and Water & \\
16 Construction & \\
17 Commerce & \\
18 Transport & Financial and Insurance Services \\
20 Real Est. \& Business Services & \\
21 Government Services & \\
22 Other Services & \\
\hline
\end{tabular}

sector-with "metal products and machinery." Since the value-added taxes are applied equally to domestically produced goods and imports, we impose the VAT on commodities rather than activities for simplicity. STATIN data combines taxes on international trade (tariffs) with other indirect taxes, and therefore we need additional information to separate indirect taxes from tariffs. We collect these data from UN COMTRADE and TRAINS databases. We use COMTRADE for trade flows (imports and exports) at a disaggregated level, and TRAINS for applied tariff rates in the same commodity groups. This allows us to calculate the overall tariff revenue, and subtract it from other taxes.

Value Added. The disaggregation of total value added by sector is available from STATIN. We combine this information with the earlier IFPRI SAM to disaggregate total value added into capital, labor, and indirect tax components. We also take advantage of the information in the Labor Force survey to ensure that the labor value added by sector is consistent with the aggregate survey results. In order to ensure that all of these constraints are satisfied, we use the RAS technique to estimate the shares of labor, capital, and indirect taxes. 
Taxes. We use the VAT tax rates reported in the IFPRI SAM and apply them to the value added calculated in the previous step. We then adjust tax collection by sector to get the VAT total consistent with the macro SAM. Payroll taxes are not explicitly identified in the SAM - they are calculated within the model using a universal the payroll tax rate.

Intermediate and Final Demand. We use the shares of intermediate consumption to total value added from the IFPRI SAM to obtain a table of input coefficients, which are then applied to our data. Household consumption shares by commodity are calculated from the Survey of Living Conditions, and are quite close to those reported in the IFPRI SAM. We assume that the government consumes only its own services. Aggregate investment (net of stock changes) is split into sectoral investment using coefficients from the IFPRI SAM.

International Trade. Data on merchandise imports, exports, and tariffs is obtained from UN COMTRADE and UN TRAINS. In order to impute service imports and exports (which include tourism), we use the IFPRI SAM to disaggregate total service exports and imports.

The resulting social accounting matrix is quite unbalanced, although the imbalances are limited to the commodity rows and columns. We balance this SAM using a cross-entropy approach which allows only the input-output coefficients to move (the input-output coefficients from the IFPRI SAM serve as a starting point). This implies that we trust our final demand estimates (which come from the survey and COMTRADE data) and allow the production structure to change slightly.

\section{B. A Brief Description of the CGE Model}

Production. Output results from nested CES (Constant Elasticity of Substitution) functions that, at the top level, combine intermediate and value added aggregates. At the second level, the intermediate aggregates are obtained combining all products in fixed proportions (Leontief structure), and total value added is obtained by aggregating the primary factors. The full structure of production nests is shown in Figure 3.

Income Distribution and Absorption. Labor income and capital revenues are allocated to households according to a fixed coefficient distribution matrix derived from the original SAM. Private consumption demand, as well as labor supply decisions, is obtained through maximization of household specific utility function following the Linear Expenditure System (LES). Household utility is a function of consumption of different goods and leisure. Once total value of private consumption is 
Figure 3. Production Structure of the Jamaica CGE Model

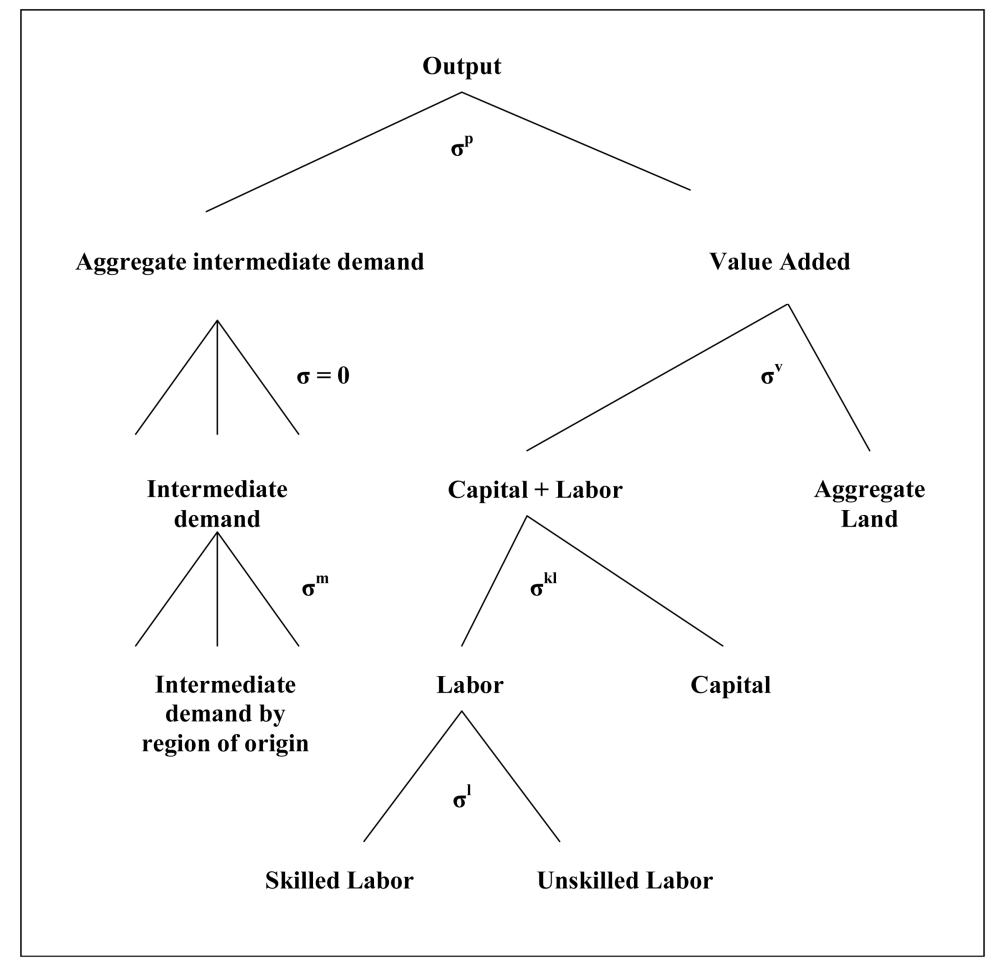

Note: Although the model allows substitution between Land and the other primary factors, given that the data for separating land and other factors contributions to value added was not available, the nesting structure actually active in the current model does not include Land as a separate factor.

determined, government and investment demand are disaggregated into sectoral demands according to fixed coefficient functions.

International Trade. The model assumes imperfect substitution among goods originating in different geographical areas. ${ }^{25}$ Import demand results from a CES aggregation function of domestic and imported goods. Export supply is symmetrically modeled as a Constant Elasticity of Transformation (CET) function. Producers allocate their output to domestic or foreign markets according to relative prices. Under the small country assumption, Jamaica is unable to influence world prices and its imports and exports prices are treated as exogenous. Assumptions of imperfect substitution and imperfect transformability grant a certain degree of autonomy of domestic prices with respect to foreign prices and prevent the model from generating corner solutions. Furthermore, they permit cross-hauling-a

\footnotetext{
${ }^{25}$ See Armington (1969) for details.
} 
feature normally observed in real economies. The balance of payments equilibrium is determined by the equality of foreign savings (which are exogenous) to the value of the current account. With fixed world prices and capital inflows, all adjustments are accommodated by changes in the real exchange rates: increased import demand, due, for instance, to trade liberalization, must be financed by increased exports, and these can expand due to improved resource allocation. Import price decreases drive resources towards export sectors and contribute to falling domestic resource costs (or real exchange rate depreciation).

Factor Markets. Labor is divided into two categories: skilled and unskilled. These categories are considered imperfectly substitutable inputs in the production process. The labor market skill segmentation ${ }^{26}$ has become a standard assumption in CGE modeling and it is easily justifiable for the case of Jamaica, where inequalities in educational endowments and access to education support this assumption. Skilled and unskilled labor types are then aggregated into a composite labor bundle which is then combined with composite capital (see production nest in Figure 3). In the standard version, composite capital and labor types are fully mobile across sectors; however, in a variant version, we assume that labor markets are segmented between agriculture and non-agriculture, with labor fully mobile within each of the two broad sectors, but fully immobile across them. The restrictive conditions of this second version are imposed on the modeling framework so that it mimics more closely the behavior of the economy in the short-term when factors are less mobile across sectors. Capital supply is fixed. Labor supply, for both the skilled and unskilled categories, is derived, as shown above, from utility maximization where individuals chose the optimal consumption level for both commodities and leisure time under their budget constraint.

Model Closures. The equilibrium condition on the balance of payments is combined with other closure conditions so that the model can be solved. First, aggregate government expenditures are fixed at the base year value. Government surplus is exogenous and the household income tax schedule shifts in order to achieve this predetermined net government position. Second, aggregate investment is set equal to aggregate savings. The volume of available savings is determined by a fixed level of foreign saving, exogenous government saving, and households who save a fixed share of their post-tax income (i.e. the marginal propensity to save is fixed).

\footnotetext{
${ }^{26}$ See Taubman and Wachter (1986) for a general discussion of labor market segmentation.
} 